\title{
Mapping of Textural Variability in Soils: A Case Study
}

\author{
Hena Praveen ${ }^{1}$, M.P. Singh ${ }^{2}$, S.S. Prasad ${ }^{2}$, B.K. Vimal', \\ Sunil Kumar ${ }^{1 *}$ and A.K. Pradhan ${ }^{1}$ \\ ${ }^{1}$ Department of Soil Science and Agricultural Chemistry, Bihar Agricultural University, \\ Sabour, Bhagalpur-813210, Bihar, India \\ ${ }^{2}$ Department of Soil Science, Dr. Rajendra Prasad Central Agricultural University, Pusa, \\ Samastipur-848125, Bihar, India \\ *Corresponding author
}

\section{A B S T R A C T}

This study uses data from Global Positioning System and Geographic Information System to produce digital maps for soil texture using the spatial analysis technique. Soil texture is

\section{Keywords}

Geospatial analysis, RS-GIS, Ordinary Kriging, Soil texture, Sandy-loam

Article Info

Accepted:

12 April 2018

Available Online:

10 May 2018 one of the most important soil properties whose variability may contribute to the variation in nutrient storage and availability, water retention and transport, and binding and stability of soil aggregates. It can directly or indirectly influence many other soil functions and soil threats such as soil erosion. Geostatistics has been extensively used for quantifying the spatial pattern of soil properties and Kriging techniques are proving to be sufficiently robust for estimating values at unsampled locations in most of the cases. In our study, we show the applicability of Ordinary Kriging techniques to characterize the spatial variation in soil texture. To achieve this objective, thematic soil maps clearly revealed the distribution of selected physical characteristics which were assigned appropriate classes, i.e. low, medium and high. The maximum spatial distribution of soil texture was found for loamy sand $(40.52 \%)$. Bulk density of 1.45 to $1.5 \mathrm{Mg} \mathrm{m}^{-3}$ was found over $80.86 \%$ of the study area, while the clay content of 15 to $20 \%$ was recorded over $51.11 \%$ of total area. The slope $(0-3 \%)$ suggested the area to be having low land topography. The thematic layers of these data were created in TNT Mips 2010 geospatial software.

\section{Introduction}

Soil, a valuable natural resource has been considered as a fundamental to human existence. Over this concern, survey and mapping of the soil pattern provided an opportunity for management and optimum utilization. In context of preparation of digital soil map, Geo-informatics technology is now demand to produce the latest and update of nutrient status of the farm that may help in taking decision for site specific nutrient management. Our ability to understand and manage the soil resource is dependent on the scale at which we can observe and model soil characteristics and processes. As soil scientists, one of our key challenges is to produce information about soil quality and processes at a resolution and extent useful for decision makers (Lark, 2005; Malone et al., 2013). It may often be necessary to do this without the collection of additional data 
(Malone et al., 2013; Pongpattananurak et al., 2012). Patil et al., 2011 reported that knowledge of spatial variability towards soil fertility is fruitful for the assessment of site specific nutrient management. Thematic maps of an area and production of tea in North East India were prepared and reported by Sakia and Bhagat, 2012, so that the trends can be visualized and could be managed accordingly. Due to reliable, rapid and cost effective tools, remote sensing and Geographic Information System (GIS) techniques were used by Saxena et al., 2000 for the collection of data on status of natural resources over large areas. Srinivas Vitalla et al., 2004 delineated the drainage pattern from topographic maps and updated with satellite imagery, and carried morphometrical and physiographic properties for sub-watersheds using GIS techniques, and concluded that the conventional methods of topographical analysis are time consuming, tiresome and error prone, while the use of GIS techniques allows for more reliable and accurate estimation of parameters. Jain et al., 2001 estimated soil erosion by RS-GIS techniques from a Himalayan watershed in which two different soil erosion models were developed. Singh et al., 2002 carried out study on prioritization of Bata river basin using Remote Sensing and GIS and identified the geographical area wise suitable site.

Nigam 2000 reported that Remote Sensing provided a synoptic view and multi- temporal land uses/ land cover pattern of an area that helped to take decision over land use planning. Similarly, Singh et al., (2012) reported that Remote Sensing and Geographical Information System may be applied to generate different thematic maps towards land resource evaluation. At the present scenario, an estimation of textural variation over cultivated land for the adaptation of contingent plan under RS-GIS domain is a researchable issue. Keeping in view and to short out the problem, the present study was carried out.

\section{Materials and Methods}

Agricultural farm of Rajendra Agricultural University, Pusa has been selected as study area, is fallen under Samastipur district of Bihar. The area is U shaped South-West lap of river Burhi Gandak at an altitude of $52.0 \mathrm{~m}$. It has an area of 485 ha, bounded with latitude $25^{\circ} 58^{\prime} 54^{\prime \prime} \mathrm{N}$ to $25^{\circ} 59^{\prime} 28.91^{\prime \prime} \mathrm{N}$ and longitude $85^{\circ} 40^{\prime} 25^{\prime \prime} \mathrm{E}$ to $85^{\circ} 41^{\prime} 27.88^{\prime \prime} \mathrm{E}$ and depicted on survey of India's toposheet number $72 \mathrm{G} 9$ of scale 1:50,000. Pusa comes under the North-West alluvial plain (Zone-1) of Bihar. Most of the land in the site area is used for research, seed production and forage production and remaining area includes administrative, academic, and residential premises. Sparse forest lands and orchards are the other land cover types. The major agricultural crops are rice, wheat, maize, sunflower, pea, potato, sugarcane and vegetables.

The climate of the study area is semi-arid, with a hot summer during March to June, cold winter during November to February and a rainy season during July to October. The annual mean maximum and minimum temperatures are $38^{\circ} \mathrm{C}$ and $19^{\circ} \mathrm{C}$ respectively, mean annual rainfall is $1123 \mathrm{~mm}$, the mean evaporation is $4.66 \mathrm{~mm} / \mathrm{day}$, the average relative humidity is $87 \%(\mathrm{RH} 1)$ and $57 \%$ (RH 2) and the annual average wind velocity $4.63 \mathrm{~km} / \mathrm{h}$. Major soil types included calcareous and fluvents in nature, Ustifluvents dominated over all the other soil type.

Geologically the area is part of Indo- is Gangetic plain consisting of thick alluvial mantle of drift origin of Siwalik and tertiary rocks. The elevation of the land varies from $50-60 \mathrm{~m}$ with a very low average slope ranging from 1 to $5 \%$. The slope gradient of the region, comprising this belt, points southeast to east and is very gentle. The drainage poor; and the water table remains very near 
the surface, i.e. within one metre depth, during larger part of the year. The region suffers from widespread flooding; and the low lying areas, like the old river channels and other depressions remain water-logged throughout the rainy season.

Map obtained from Google Earth was georeferenced in GIS environment using six known location of the Pusa farm boundary. The exact latitude and longitude were incorporated in the image and saved. The digitization of visible features of Pusa farm performed by using point, line and polygon tools under GIS software. $200 \times 200 \mathrm{~m}$ grid map of Pusa Farm was prepared through the GIS software (MAP.1). The preparation of thematic map was performed in the GIS platform. TNT-mips 2010 is a full-featured Geographic Information System that integrates display and processing of map data, imagery, and terrain data along with the creation and management of associated relational database. All together 164 grid was marked and formed on Goggle map for the collection of Grid wise soil samples towards analysis of soil texture, bulk density and clay content. Burdhi Gandak River, River bund, Roads, Research plots, Irrigation Tube well were marked by vector tools.

Sampling point was navigated by Hand Held Global Positioning System (Magellan made Mobile Mapper-CX). From the grid cell at random, soil samples for surface $(0-15 \mathrm{~cm}$ depth) were collected, all together 149 soil samples were collected and were air dried in shade and grounded to pass through $2 \mathrm{~mm}$ sieve and kept in polythene bags separately along with the proper labels were linked to the soil sampling GPS Points by import action of the GIS software. Over this concern, Interpolation is the process of determination of point values on the surface by the known point data. The thematic soil maps were prepared for soil texture, bulk density and clay content.

\section{Results and Discussion}

Coordinates of soil sample sites with Unique ID and other general information like vegetation, slope, geography and drainage have been presented. The study area has lowland, med upland and upland with 0-3\% slope, poorly to moderately well drained soils and a variety of vegetations from grasses to trees.

\section{Bulk density}

In context of Bulk density, varied from 1.41 to $1.56 \mathrm{Mg} \mathrm{m}^{-3}$ with mean and standard deviation value of 2.33 and \pm 0.035 . Thematic map of bulk density (Map 1.) It indicated highest $80.86 \%$ area with bulk density 1.45 to $1.5 \mathrm{Mg}$ $\mathrm{m}^{-3}$, followed by $10.2 \%$ area with bulk density less than $1.45 \mathrm{Mg} \mathrm{m}^{-3}$ and $8.94 \%$ area of bulk density greater than $1.50 \mathrm{Mg} \mathrm{m}^{-3}$.

The spatial distribution of bulk density 1.45 to 1.5 were observed in almost major part of study area whereas, less than 1.45 and greater than 1.5 bulk density were found with uneven distribution in Jhilli, Nursery, IARI (Pusa), Mansur plot, Crop Research Center (IARI), Livestock and Dhab area. The range of bulk density is similar as reported by Kumar (2006) and Nekee Sweta (2014) for the plots of Pusa Farm (Fig. 1).

\section{Soil texture}

In the study area, soil texture varied from loamy sand to clay loam, Thematic map of soil texture (Map 2) clearly reveals its spatial distribution.

It indicated highest $40.52 \%$ area as loamy sand, followed by $24.31 \%$ area as sandy loam, $18.51 \%$ area as silt loam, $12.64 \%$ area as loam, $3.34 \%$ area as silt clay loam, $0.67 \%$ area as sandy clay and $0.01 \%$ area as clay loam texture of the surface soil (Fig. 2). 


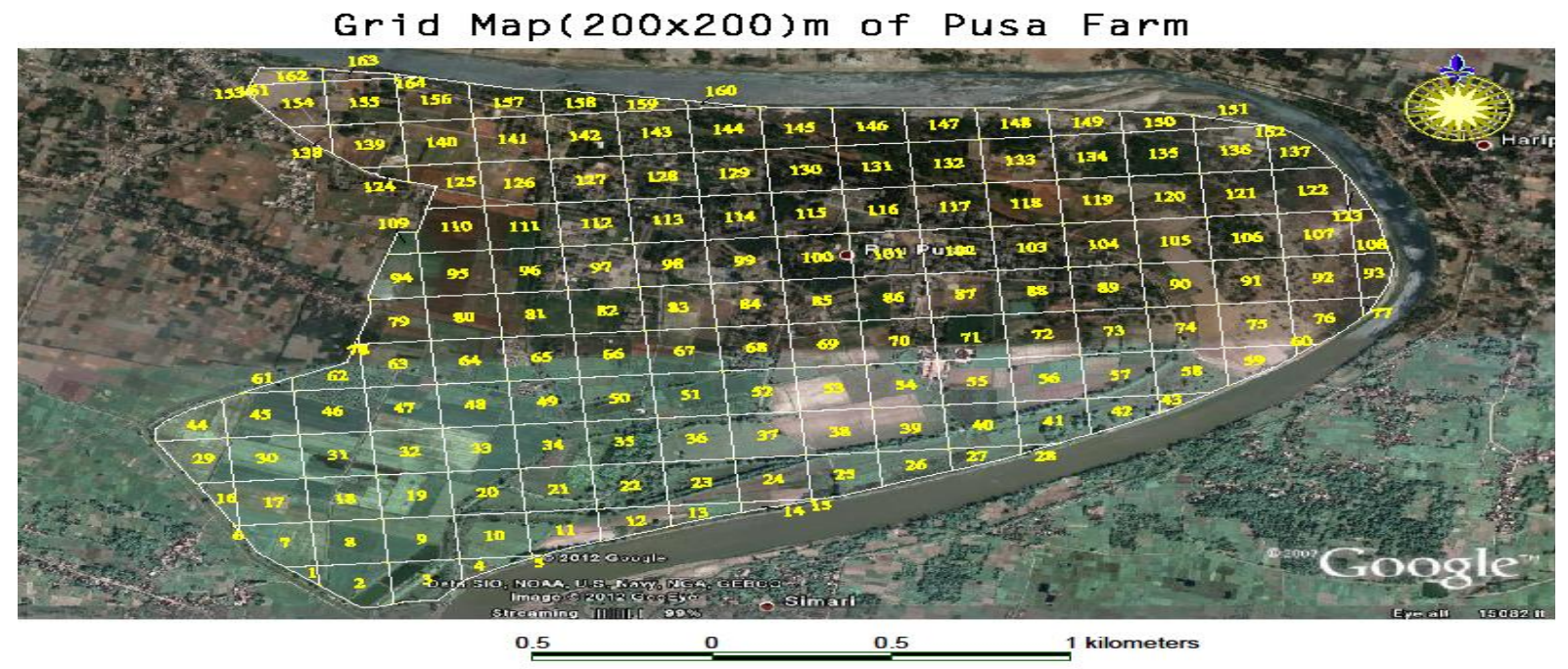

Fig.1 Distribution of bulk density

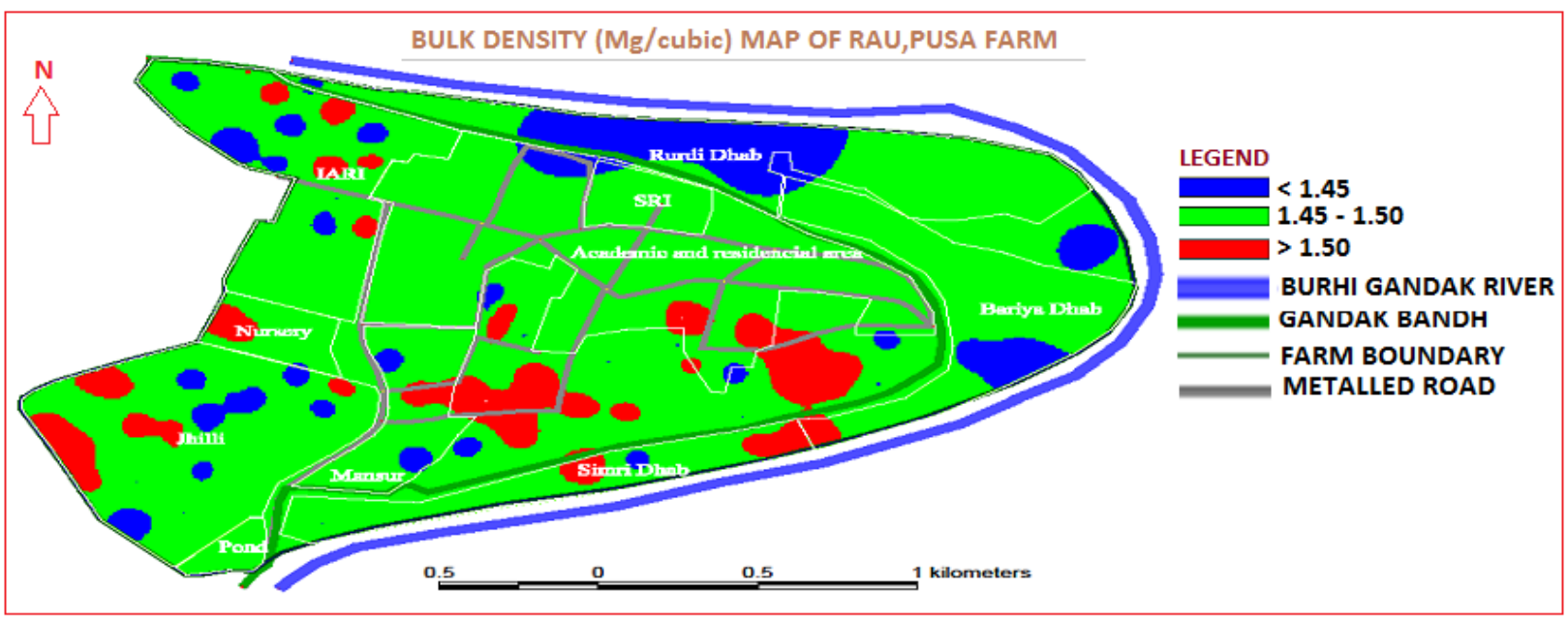

Fig.2 Distribution of soil texture

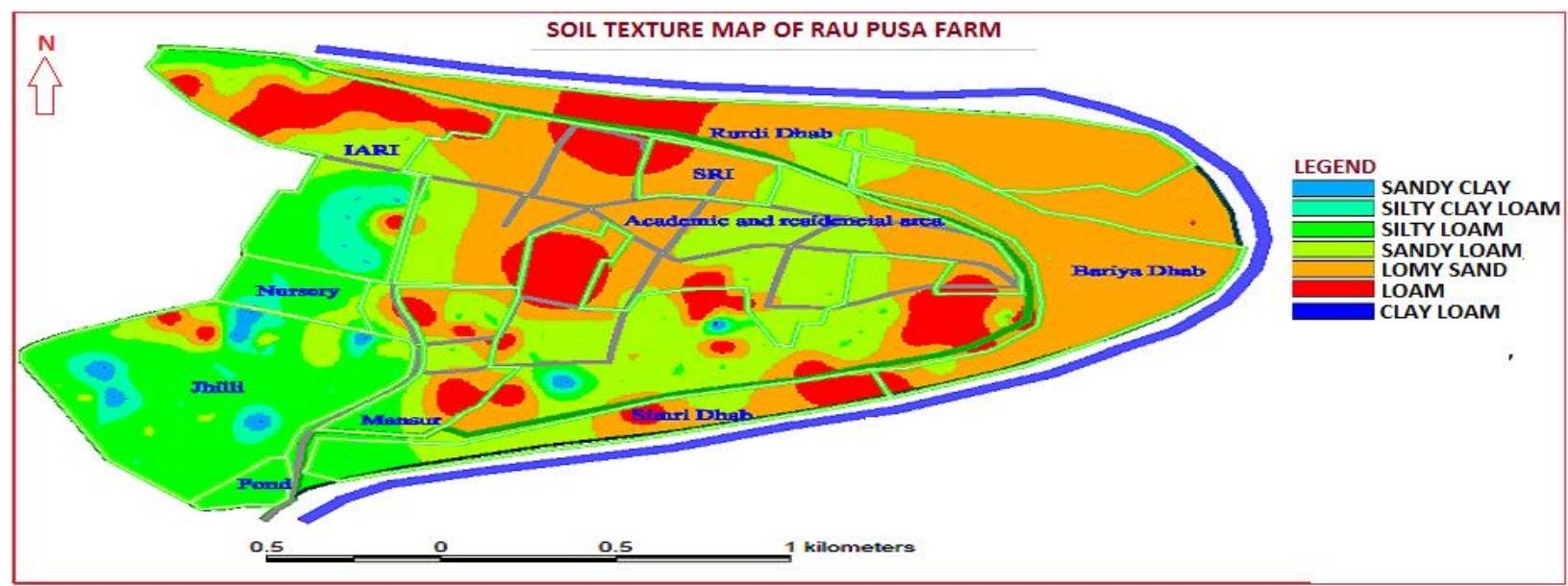


Fig.3 Distribution of soil clay content

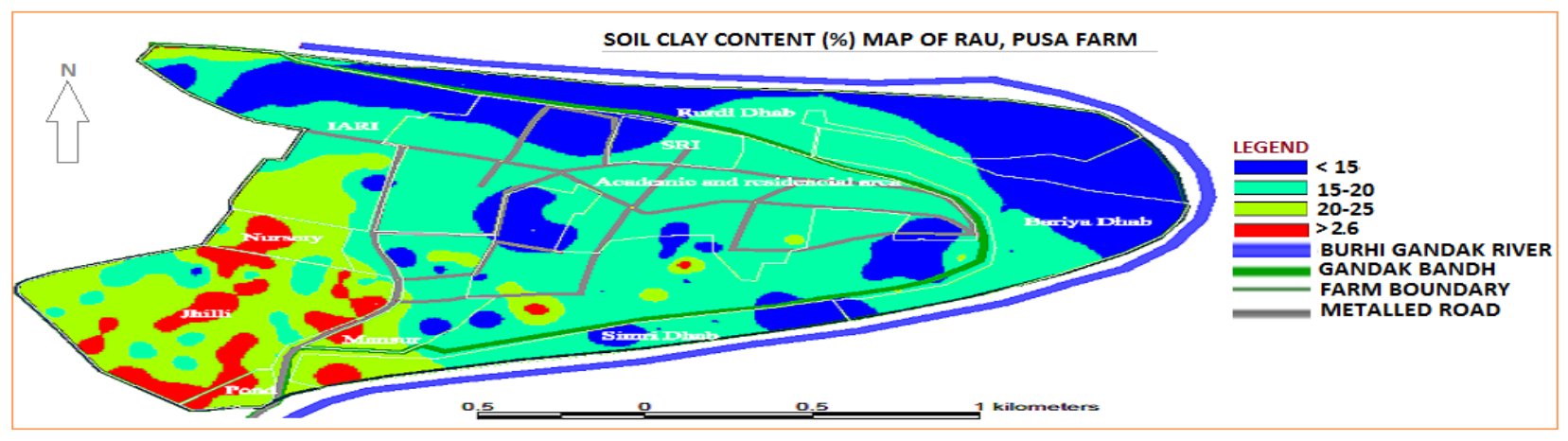

The spatial distribution of surface soil texture loamy sand and sandy loam were observed in upland, medium upland and some part of lowland area comprising Jhilli, Nursery, IARI (Pusa), Mansur plot, Crop Research Center (IARI), Livestock area, Sugarcane Research Institute (SRI) and Dhab area. Silt loam was found in parts of Jhilli, Nursery, IARI (Pusa) and Mansur plot whereas loam was scattered all over the study area. The distribution of surface soil texture silt clay loam was found in small patches in Jhilli, Nursery, IARI (Pusa) and Crop Research Center (IARI). The distribution of surface soil texture sandy clay and clay loam were observed in small pockets in Jhilli, Nursery, IARI Pusa and Crop Research Center (IARI). The results are in accordance with the observations of Singh (1989) for three profiles of Pusa, Farm.

\section{Clay content}

The spatial distribution of clay content were observed between 15 to $20 \%$ in all part of the study area, whereas, less than $15 \%$ clay content were observed in parts of IARI, SRI, Mansur plot, Crop Research Center (IARI), Livestock area, Kisan Vidyapith, Dhab and Jhilli, Nursery area. Clay content 20 to $25 \%$ were observed in lowland and medium upland area comprising Jhilli, Nursery, IARI, Livestock area, Kisan Vidyapith, Mansur plot and Crop Research Center (IARI) whereas, greater than $25 \%$ clay content were found in Jhilli nursery and Crop Research Center (IARI). Clay contents were in the range reported by Singh (1989) and Rupali
(2014) from plots of Pusa Farm. Clay content varied from 10 to $29 \%$ with mean and standard deviation value of 18.75 and \pm 5.44, respectively table 2 , and its distribution have been presented graphically. Thematic map of clay content (Map 5) clearly reveals its spatial distribution. It indicated highest $51.11 \%$ area having clay content 15 to $20 \%$, followed by $26.86 \%$ area having clay content less than $15 \%$, $17.03 \%$ area having clay content $20-25 \%$ and $5.03 \%$ area having more than $25 \%$ clay content (Fig. 3).

Observations were recorded under low land topography (slope 0-3\%) adjoining of the river Burdhi Gandak. Poorly to moderately well drained soils and a variety of vegetation from grasses to plantation. Surface soil texture varied from loamy sand to clay loam, largest area being loamy sand $(40.52 \%)$ followed by sandy loam $(24.31 \%)$, silt loam $(18.51 \%)$, loam $(12.64 \%)$, silty clay loam (3.34\%), sandy clay $(0.67 \%)$ and clay loam $(0.01 \%)$. In case of Bulk Density, it varied from 1.41 to $1.56 \mathrm{Mg} \mathrm{m}^{-3}$ with mean value of $1.48 \mathrm{Mg} \mathrm{m}^{-3}$, largest area being $80.86 \%$ with bulk density 1.45 to $1.5 \mathrm{Mg} \mathrm{m}^{-3}$ followed by $10.2 \%$ area with bulk density less than $1.45 \mathrm{Mg} \mathrm{m}^{-3}$ and $8.94 \%$ area greater than $1.50 \mathrm{Mg} \mathrm{m}^{-3}$. Clay content in soils is very low and varied from 10 to $29 \%$ with mean value of $18.75 \%$, largest $51.11 \%$ area having clay content 15 to $20 \%$, followed by $26.86 \%$ area having clay content less than $15 \%, 17.03 \%$ area having clay content $20-25 \%$ and $5.03 \%$ area having more than $25 \%$ clay content that indicated the light texture. 


\section{Acknowledgement}

Chairman, Department of Soil Science, Dr.R.P.C.AU, Pusa (Samastipur) is thankfully acknowledged for his valuable suggestions and providing laboratory facilities.

\section{References}

Jain S.K. (2001) Issues in sustainable development of water resources. Journal of Indian Water Resources Society 21, 20-23.

Kumar, V. (2006) Mulching in relation to phosphorous nutrition in autumn planted sugarcane. M.Sc. Thesis. Dept. of soli science Rajendra Agricultural University, Bihar, Pusa

Lark, R.M., 2005. Exploring scale-dependent correlation of soil properties by nested sampling. Eur. J. Soil Sci. 56 (June), 307317

Malone, B.P., McBratney, A.B., Minasny, B., Laslett, G.M., 2009. Mapping continuous depth functions of soil carbon storage and available water capacity. Geoderma $154(1-$ 2), 138-152.

Nigam K. (2000) Application of Remote Sensing and Geographical Information System for Land Use / Land Cover Mapping and Change Detection in the Rural Urban Fringe Area of Enschede City, the Netherlands International Archives of Photogrammetry and Remote Sensing. Vol. XXXIII, Part B7. Amsterdam.

Patil, S.S., Patil, V.C. and K.A. Al-Gaadi (2011) Spatial Variability in Fertility Status of Surface Soils. World Applied Sciences Journal 14: 1020-1024, ISSN 1818-4952.

Pongpattananurak, N., Reich, R.M., Khosla, R., Aguirre-Bravo, C., 2012. Modeling the spatial distribution of soil texture in the state of Jalisco, Mexico. Soil Sci. Soc. Am. J.76 (1), 199.
Rupali (2013) Screening of maize varieties to zinc stress in calcareous soil. M.Sc. Thesis. Dept. of soli science. Rajendra Agricultural University, Bihar, Pusa.

Saikia, M, and Bhagat, R.M. (2012) A GIS approach to generation of thematic maps to monitor tea plantations: A case study. Two and a Bud 5: 41-45.

Saxena, R. K., Verma, K. S., Chary, G.R., Srivastava, R. and Bartwal, A. K., IRS-IC data application in watershed characterization and management, 2000, International Journal of Remote Sensing, 21, 3197-3208.

Singh, M. P. (1989) Pedogenesis, classification and landscape relationship of a salt affected calcareous soil. M.Sc. Thesis. Dept. of soli science Rajendra Agricultural University, Bihar, Pusa.

Singh, R. B. and Dilip Kumar (2012) Remote sensing and GIS for land use/cover mapping and integrated land management: case from the middle Ganga plain. Journal of Front. Earth Sci. (springer) pp.167-176.

Singh, R.K., Aggarwal, S.P., Turdukulov, U., Hariprasad, V. (2002) Prioritization of Beta river basin using Remote Sensing \& GIS technique. Indian Journal of Soil Conservation 30 200-205

Srivnivasa Vittala S., Govindaiah S. and Honne Gowda H. (2004) Morphometric Analysis of Sub-Watersheds in the Pavagada Area of Tumkur District, South India using Remote Sensing and GIS Techniques, Journal of the Indian Society of Remote Sensing 4: 117129.

Sweta Nekee (2014) Long-term effects of organic and inorganic fertilizers application on phosphorous transformation under RiceWheat cropping system in calcareous soil. M.Sc. Thesis. Dept. of soli science. Rajendra Agricultural University, Bihar, Pusa.

\section{How to cite this article:}

Hena Praveen, M.P. Singh, S.S. Prasad, B.K. Vimal, Sunil Kumar and Pradhan, A.K. 2018. Mapping of Textural Variability in Soils: A Case Study. Int.J.Curr.Microbiol.App.Sci. 7(05): 1568-1573. doi: https://doi.org/10.20546/ijcmas.2018.705.186 